\title{
Serum Sialic Acid in Normals and in Cancer Patients
}

\author{
By R. J. Shamberger \\ The Cleveland Clinic Foundation, Department of Biochemistry, Cleveland, Ohio, USA
}

(Received January 19/July 5, 1984)

Summary: A simple procedure is described for the detection of sialic acid in serum. After a direct addition of Ehrlich reagent to serum and an incubation at $56^{\circ} \mathrm{C}$ for eight hours, the resulting mixture is diluted with saline. After centrifugation, the color in the supernatant is determined at $525 \mathrm{~nm}$ in a spectrophotometer. Serum sialic acid was significantly greater in cancer patients than in normals. Cancer patients with metastases had significantly greater sialic acid than cancer patients without metastases. In two cancer patients, sialic acid levels returned to normal after surgery. The diagnostic usefulness of $95.6 \%$ was similar to that reported with lipid-soluble sialic acid and seemed to be superior to CEA and other tumor antigens associated with a limited spectrum of tumors. However, patients with inflammatory diseases such as arthritis, Crohn's disease and psoriasis also showed elevated sialic acid levels.

Ultrafiltration showed that almost all of the sialic acid was retained on an Amicon filter, which suggests that sialic acid was bound to a macromolecule. A quality control serum run 25 times had a coefficient of variation (CV) of $8.4 \%$ and the same serum ran on 42 days had a CV of $11.6 \%$.

\section{Sialinsäure im Serum von Gesunden und Patienten mit Carcinomen}

Zusammenfassung: Ein einfachẹs Verfahren zum Nachweis von Sialinsäure im Serum wird beschrieben. Nach Zugabe von Ehrlichs Reagenz direkt zum Serum und Inkubation für 8 Stunden bei $56^{\circ} \mathrm{C}$ wird das Gemisch mit physiologischer NaCl-Lösung verdünnt. Nach Z̈entrifugation wird die Farbintensität des Úberstandes bei $525 \mathrm{~nm}$ in einem Spektralphotometer bestimmt. Die Sialinsäurekonzentration war im Serum von Carcinompatienten signifikant höher als im Serum von Gesunden. Sie war bei Patienten mit Metastasen höher als bei denen ohne Metastasen. Bei zwei Patienten fiel die Sialinsäürekonzentration nach Operation auf bei Gesunden gefundene Werte ab. Der diagnostische Wert der Ergebnisse dieses Bestimmungsverfahrens von $95,6 \%$ ist vergleichbar mit dem für lipidlösliche Sialinsäure berichteten und scheint den von carcinoembryonalem Antigen und anderen Tumorantigenen, die bei einem begrenzten Spektrum von Tumoren vorkommen, zu übertreffen; jedoch zeigten auch Patienten mit entzündlichen Erkrankungen wie Arthritis, Morbus Crohn und Psoriasis ernhöhte Sialinsäurekonzentrationen.

Ultrafiltration zeigte, daß fast die gesamte Sialinsäure an Amicon-Filtern zurückgehalten wurde, weil Sialinsäure wahrscheinlich an ein Makromolekül gebunden isț. Der Variationskoeffizient in der Serie $(\mathrm{N}=25)$ wurde mit einem Qualitätskonntrollserum zu 8,4\% ermittelt. Er betrug mit dem selben Serum von Serie zu Serie $(\mathrm{N}=42) 11,6 \%$.

\section{Introduction}

Several glycosyltransferase levels have been reported to be abnormal in human cancer $(1,2)$. The catalytic concentrations of one enzyme, sialyltransferase were found to be elevated in sera obtained for both animals and humans bearing metastasizing tumors $(3-6)$. Serum sialyltransferase and 5 '-nucleotidase were found to be reliable biomarkers of breast cancer activity, and serial measurements of these enzyme activities were used for the monitoring of disease activity and success or failure of the treatment 
(7). Serum sialic acid and sialyltransferase have also been used to monitor tumor burden in malignant melanoma patients ( 8 ), but sialic acid levels appeared to more closely reflect tumor burden than sialyltransferase activity. Lipid-bound sialic acid and sialic acid have also been observed to be significantly elevated in cancer patients (9). In other studies, lipid-bound sialic acid was also found to be elevated in cancer patients $(10,11)$.

The methods associated with sialyltransferase measurement, lipid associated sialic acid, and sialic acid are somewhat complex for clinical laboratories. The objective of these experiments is to try to find a less complex way to measure serum sialic acid. In these experiments, Ehrlich's reagent is added directly to serum and after a long incubation, the mixture is diluted, centrifuged, and read directly on a spectrophotometer. This method was used to measure sialic acid in the sera of patients with cancer and other diseases.

\section{Material and Method}

\section{Sera studied}

Sialic acid level was measured in the sera from 134 normal males and females and 160 cancer patients of which 63 had known metastases. All cancer patients were verified by a biopsy, or pathological examination of their cancer after surgery. The following are the types of cancers and number of patients studied: breast (11); rectal (14); uterine (23); leukemias and lymphomas (21); pancreatic (4); lung (14); larynx (9); colon (8); ovarian (5); testis (3); Hodgkin's disease (4); renal (3); bladder (3); esophageal (4); melanoma (7); prostate (4); and 23 patients with several other types of cancer; (4) with sarcomas, and cancer, and (5) with brain tumors. Sialic acid level was also measured in several patients with various types of inflammatory disease: arthritis (42), psoriasis (14) Crohn's disease (13), and ulcer (3).

\section{Sialic Acid Assay}

Water $(0.5 \mathrm{ml})$ was added to $0.5 \mathrm{ml}$ serum. Blank tubes contained $1 \mathrm{ml}$ of water. At that time, $0.2 \mathrm{ml}$ of Ehrlich solution was added and the solution was vortexed. Ehrlich's reagent is made by adding $0.7 \mathrm{~g}$ of $p$-dimethylaminobenzaldehyde to $150 \mathrm{ml}$ of concentrated $\mathrm{HCl}$ and $100 \mathrm{ml}$ of distilled water. Ehrlich's reagent has been previously used to measure sialic acid (12).

A white precipitate forms immediately. The tube was covered with parafilm and its contents were then incubated in a $56^{\circ} \mathrm{C}$ water bath for 8 hours. The tubes were agitated gently at $1,3,5$ and 7 hours. The contents of the tubes gradually turned blue in the eight hour incubation period. At the conclusion of the incubation, $3.0 \mathrm{ml}$ of $9 \mathrm{~g} / \mathrm{l} \mathrm{NaCl}$ solution are added to each tube and they were centrifuged at $2500 \mathrm{~g}$ for 15 minutes. The supernatant was removed but sometimes contained some precipitate because of mixing during supernatant removal. The supernatant was recentrifuged at $2500 \mathrm{~g}$ for 15 minutes and then placed in a cuvet, which was read in a Pye-Unicam spectrophotometer at $525 \mathrm{~nm}$. The color was quite stable and could be read 16 hours later with no substantial difference in the absorbance. In two recovery studies in which 5 and $10 \mu \mathrm{mol}$ were added to $1.8 \mu \mathrm{mol}$ in $1 \mathrm{ml}$ of serum, the amounts recovered were $6.7 \mu \mathrm{mol}(98.5 \%)$ and $11.5 \mu \mathrm{mol}$ $(97.5 \%)$. Although there is no established reference method for sialic acid, one serum was run ten times by this method and the periodate oxidation-thiobarbituric acid-cyclohexanone method
(8). The results by this method were $1.90 \pm 0.13$ and $1.85 \pm 0.15$ $\mathrm{mmol} / \mathrm{l}$ by the other method. Ehrlich's reagent is also known to react with urobilinogen, but this complex has an absorption maximum at $562 \mathrm{~nm}$. The good recovery experienced seems to indicate that the method is sufficiently specific.

The assay was at least linear to an absorbance of 0.630 corresponding to $0.59 \mathrm{mmol} / /$ serum. The serum could be diluted $1: 2$ or 1:4 with proportional changes in the absorbance. Grossly hemolyzed samples, icteric samples, and lipemic samples changed appearance during the long incubation. After the incubation and centrifugation, the supernatant from lipemic and icteric samples could not be visually identified among the other samples. Grossly hemolyzed samples, after incubation, appeared to have a browner precipitate, but had no visible difference in the supernatant. Chemistry control serum I-Highland Q-pak was used as a quality control sample. This quality control sample was run 42 times on a day-to-day basis and in another experiment, 25 samples were run. CEA (Hoffmann LaRoche) levels were compared to sialic acid levels in 10 cancer patients and in two normals.

Sialic acid levels were recorded before and for four days after surgery in a 47-year-old female with breast cancer and in a 57year-old male with colon cancer. After searching the medical records it was observed that 53 patients had died from cancer or cancer-related complications. To test whether sialic acid levels might be related to the severity of the disease, sialic acid levels were compared to the time of death in these patients. In another experiment to determine the amount of free and bound sialic acid in serum, serum was passed through an Amicon filter Centriflo Ultrafiltration Membrane Cones, CF-50A which is routinely used to measure ultrafilterable calcium. Sialic acid levels were determined on the filtrate.

\section{Results}

With the method described above, there was gradual increase of color until the seventh hour of incubation when the increase of absorbance seemed to plateau (fig. 1). In contrast, standard sialic acid reached maximum color action in 45 minutes. Apparently sialic acid was gradually released from some macromolecule in the serum. Ultrafiltration showed that almost all of the sialic acid was retained on the filter indicating that sialic acid was bound to a macromolecule such as glycoprotein.

Patients with breast, rectal, uterine, pancreatic, lung, laryngeal, colon, ovarian, testicular, bladder, esophageal, and prostatic cancer as well as patients with melanoma, Hodgkin's disease and leukemia or lymphoma had significantly greater sialic acid levels ( $\mathrm{P}$ $<0.001$ ) than the controls (tab. 1). Of the 160 cancer patients in table $1,151(94 \%)$ had sialic acid levels greater than 2 standard deviations (S.D.) of the controls. Of the 9 patients who did not have sialic acid values greater than the controls, one patient with uterine cancer and one with rectal cancer had received radiation treatment either the same day or the day before blood was drawn. In addition, 4 of 4 sarcoma patients had elevated sialic acid levels. The results were: bone sarcoma 2.6,2/2; and leiomysar= coma 2.6, 2/2. Brozmanova \&iSkrovina (13) have 


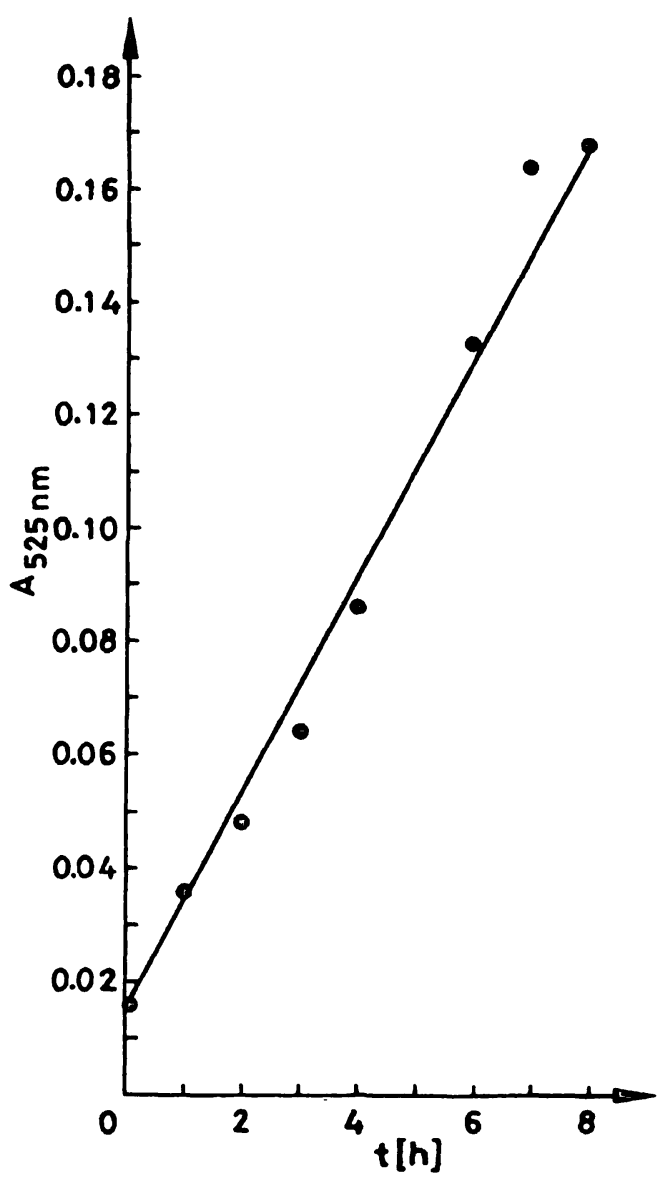

Fig. 1. The relationship between the color development of sialic acid (absorbance) and time.

also observed significant elevation of sialic acid among sarcoma patients compared to normals or patients with benign neoplasms. The number elevated beyond two standard deviations of normal and the type of brain tumors studied included: glioblastomas $2.6,2 / 3$; glioma $1.8,0 / 1$; and a craniopharyngioma $2.7,1 / 1$. Of the 134 normals, 6 had values greater than 2 S.D. of the mean and werre false positives.

One hundred and thirty-four normals had a serum sialic acid level of $1.74 \pm 0.24$ (S.D.) $\mathrm{mmol} / \mathrm{l}$ whereas 160 cancer patients had a level of $2.99 \pm 0.72$ and 63 cancer patients with metastases had a level of $3.23 \pm 0.73$. Using a t-test of significance both the cancer patients and cancer patients with metastases were significantly different than the controls $(\mathrm{P}<$ 0.001). With the $t$ test, the sialic acid level in cancer patients without metastases was also significantly different than the cancer patients with metastases. The higher sialic acid levels in the patients with metastases probably represents the greater tumor burden and sialic acid production by the cancer patients.

Figure 2 shows the five day postoperative sialic acid levels in a 52-year-old man with colon cancer and a 43-year-old woman with breast cancer. After the
Tab. 1. Serum sialic acid levels in cancer paticnts.

\begin{tabular}{|c|c|c|c|c|}
\hline Type & $N$ & $\begin{array}{l}\text { Sialic acid } \\
(\mathrm{mmol} / \mathrm{l})\end{array}$ & $\begin{array}{l}\text { Valucs } \\
>2 \text { S.D. } \\
\text { normal }\end{array}$ & S.D. \\
\hline Normals & 134 & 1.74 & - & 0.24 \\
\hline Breast & 11 & 2.86 & $11 / 11$ & $0.49 *$ \\
\hline Rectal & 14 & 2.99 & $13 / 14$ & $0.62 *$ \\
\hline Uterine & 23 & 2.74 & $22 / 23$ & $0.61 *$ \\
\hline Lcukemics \& lymphoma & 21 & 3.06 & $21 / 21$ & $\left(0.7()^{*}\right.$ \\
\hline Pancreas & 4 & 3.20 & $4 / 4$ & $0.71^{*}$ \\
\hline Lung & 14 & 3.69 & $14 / 14$ & $1 .(1) *$ \\
\hline Larynx & 9 & 2.69 & $8 / 9$ & $0.46^{*}$ \\
\hline Colon & 8 & 3.19 & $8 / 8$ & $0.78^{*}$ \\
\hline Ovarian & 5 & 2.95 & $5 / 5$ & $0.50 *$ \\
\hline Testis & 3 & 2.62 & $3 / 3$ & $0.24^{*}$ \\
\hline Hodgkin's disease & 4 & 3.44 & $4 / 4$ & $0.69^{*}$ \\
\hline Renal & 3 & 3.38 & $3 / 4$ & $0.76^{*}$ \\
\hline Bladder & 3 & 3.19 & $3 / 3$ & $0.48^{*}$ \\
\hline Esophagus & 4 & 3.31 & $4 / 4$ & $0.37^{*}$ \\
\hline Melanoma & 7 & 3.27 & $7 / 7$ & $1.16^{*}$ \\
\hline Prostate & 4 & 3.27 & $4 / 4$ & $1.16^{*}$ \\
\hline Vulva & 4 & 2.56 & $1 / 4$ & - \\
\hline Liver & 2 & 2.80 & $2 / 2$ & - \\
\hline Oral & 2 & 3.74 & $2 / 2$ & - \\
\hline Parotid & 2 & 2.06 & $0 / 2$ & - \\
\hline Thyroid & 2 & 2.40 & $2 / 2$ & - \\
\hline Tongue & 2 & 2.36 & $2 / 2$ & - \\
\hline Skin & 2 & 2.59 & $2 / 2$ & - \\
\hline Adrenal & 1 & 2.80 & $1 / 1$ & - \\
\hline Multiple myeloma & 1 & 3.43 & $1 / 1$ & - \\
\hline Nasal-pharyngeal & 1 & 3.03 & $1 / 1$ & - \\
\hline Submaxillary & 1 & 4.15 & $1 / 1$ & - \\
\hline Bone & 1 & 3.60 & $1 / 1$ & - \\
\hline Nasal & 1 & 2.22 & $1 / 1$ & - \\
\hline Ear canal & 1 & 2.16 & $0 / 1$ & - \\
\hline
\end{tabular}

* $\quad P<0.05$

- Not calculated

S.D. Standard deviation

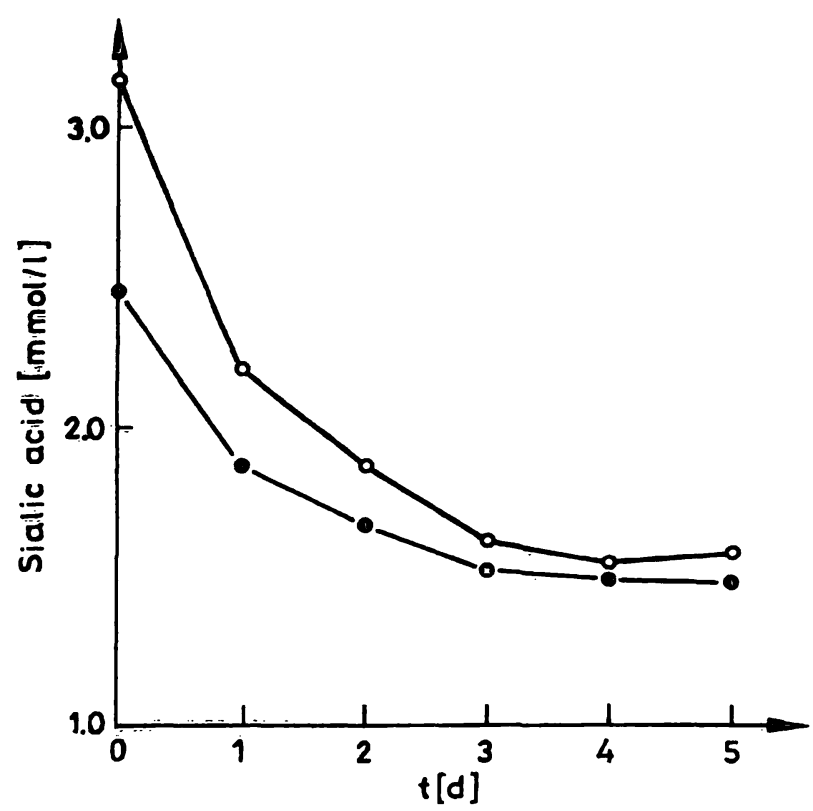

Fig. 2. Sialic acid in a 57-year-old male colon cancer patient $(\mathrm{O}-\mathrm{O})$ and a 47-year-old female breast cancer paticnt (-) before and for five days after surgery. 
cancer was removed the serum sialic acid levels returned to normal. Mrochek et al. (14) have measured protein-bound sialic acid levels in women with breast cancer. They report consistent increases in those with progressive tumor and consistent decreases in levels in patients whose disease is responding to therapy.

A correlation coefficient of $0.44(\mathrm{P}<0.01)$ was observed between sialic acid levels and days before death for 53 cancer patients (fig. 3 ), which indicates a relationship between sialic acid levels and severity of the disease. Even though one cannot predict the time of death for an individual patient, a greatly elevated sialic acid is a poor prognostic sign. Patients (tab. 2) with inflammatory diseases such as arthritis $(P<0.001)$, psoriasis $(P<0.01)$, Crohn's disease and with ulcers $(P<0.001)$ also had significantly elevated sialic acid levels.

When the diagnostic usefulness of CEA was compared to sialic acid in two normals and ten cancer patients, (tab. 3), only four of ten patients had an elevated CEA. In contrast, all 10 cancer patients had an elevated sialic acid level.

Tab. 2. Serum sialic acid levels in patients with inflammatory disease.

\begin{tabular}{|c|c|c|c|c|}
\hline Type & $\mathrm{N}$ & $\begin{array}{l}\text { Sialic acid } \\
(\mathrm{mmol} / \mathrm{l})\end{array}$ & S.D. & P* \\
\hline Arthritis & 42 & 2.77 & 0.62 & .001 \\
\hline Psoriasis & 14 & 2.34 & 0.28 & .010 \\
\hline Crohn's disease & 13 & 2.85 & 0.47 & .001 \\
\hline Ulcer & 3 & 2.56 & 1.02 & .001 \\
\hline None & 134 & 1.74 & 0.24 & - \\
\hline
\end{tabular}

* Probability of significance

S.D. Standard deviation

Tab. 3. Comparison between sialic acid* levels and CEA**.

\begin{tabular}{llr}
\hline Type of cancer & $\begin{array}{l}\text { Sialic acid } \\
(\mathrm{mmol} / \mathrm{l})\end{array}$ & $\begin{array}{r}\text { CEA } \\
(\mu \mathrm{g} / \mathrm{l})\end{array}$ \\
\hline Nonc*** & 2.04 & 2.0 \\
None*** & 2.04 & 2.0 \\
Adrenal & 2.80 & 29.9 \\
Bone sarcoma & 3.60 & 2.2 \\
Colon & 2.64 & 64.0 \\
Liver & 2.80 & 2.1 \\
Rectal & 3.50 & 32.0 \\
Rectal & 2.69 & 2.0 \\
Rectal & 2.91 & 2.0 \\
Rectal & 3.69 & 2.0 \\
Rectal & 2.98 & 103.5 \\
Stomach & 2.66 & 2.0 \\
\hline
\end{tabular}

* $1.26-2.22 \mathrm{mmol} / \mathrm{l}$

** $0-2.5 \mu \mathrm{g} / \mathrm{l}$

*** Normal probands

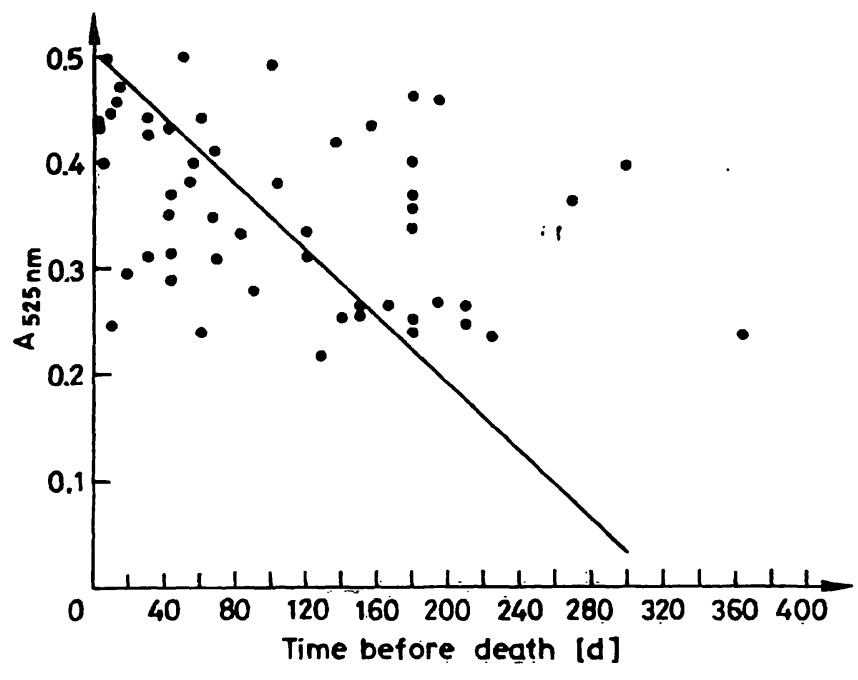

Fig. 3. The correlation between sialic acid levels and the days before death in cancer patients. $N=53 ; r=0.44 ; p<0.01$.

Hyland reference serum (Chemistry Çontrol Serum I Hyland Q-Pak) seemed to be useful as a quality control serum for sialic acid with a day-to-day $(\mathrm{N}=42)$ coefficient of variation of $11.6 \%$ and within run variation $(\mathrm{N}=25)$ of $8.4 \%$.

\section{Discussion}

Methods associated with sialyltransferase measurement, lipid-associated sialic acid, and sialic acid measurement are difficult for routine analysis by clinical laboratories because either'radioactive-labelled substrates, labile reagents, or solvent extractions are required. Sialyltransferase assay requires a precipitation of a radioactive substrate by phosphotungstic acid precipitation; sialic acid is oxidized with periodic acid and then extracted into cyclohexanone. The major advantages of the procedure reported here is that one stable reagent is added to serum and after incubation in a water bath and centrifugations, the absorbance is read in a spectrophotometer. All of this type of equipment is present in a clinical laboratory. The major disadvantage is the 8-hour.incubation plus another hour for final analysis. In addition, the method is known to be less sensitive than the thiobarbituric method (14). However, the sensitivity of the method was more than adequate. If microcuvettes were used considerably less than $0.5 \mathrm{ml}$ of serum could be used.

Previous studies have indicated that lipid-bound sialic acid may be a reliable marker in cancer (15). Of 670 cancer patients, $88 \%$ had elevated levels compared with $17 \%$ of patients with benign disease and no normal patients had elevated levels. In another 
study (8), sialic acid levels correlated with cancer diagnosis in 19 of $24(79 \%)$ patients, whereas sialyltransferase indicated cancer in 14 of the 24 patients $(58 \%)$. Changes in sialyltransferase tended to be less marked than sialic acid and the interassay variation of the enzyme assay decreased the significance of small changes. The diagnostic usefulness of sialic acid in this study was quite comparable, with $94 \%$ (151 of 160) of cancer patients showing elevated levels. There were $4.5 \%$ (6 of 134) false-positives. A comparative study between plasma lipid-bound sialic acid levels and CEA showed that 97/125 (78\%) cancer patients had elevated lipid-soluble sialic acid (10), but of the same patients only 44/125 (35\%) had elevated CEA. These numbers are comparable to the results of this small series of $100 \%$ and $40 \%$. Hogan-Ryan (16) has also observed a higher diagnostic efficiency of sialic acid (56\%) in breast cancer patients than CEA (35\%). The elevations of serum sialic acid in arthritics were similar to those reported by Silver et al. (8), who observed significant elevations of sialic acid and sialyltransferase in patients with rheumatoid arthritis. There was a tendency for both markers to be more elevated in patients with active arthritis than in patients with inactive arthritis. The elevations of serum sialic acid may be related to increases of acute phase reactants. In other studies, sialic acid levels correlated with the stage of disease $(17-20)$, tumor burden $(8,21)$, degree of metastasis

\section{References}

1. La Mont, J. T. \& Isselbacher, K. J. (1975) J. Nat. Cancer Inst. 54, 53-56.

2. Kim, Y. S. \& Isaacs, B. (1975) Cancer Res. 35, 2092-2097.

3. Bosmann, H. B., Spatara, A. C., Myers, M. W., Bernacki, R. J., Hillman, M. J. \& Caputi, S. E. (1975) Res. Commun. Chem. Path. Pharmacol. 12, 499-512.

4. Bernacki, R. J. \& Kim, Y. (1977) Science 195, 577-580.

5. Kessel, D. \& Allen, J. (1973) Cancer Res. 35, 670-672.

6. Henderson, M. \& Kessel, D. (1977) Cancer 39, 1129-1134.

7. Dao, T. L., Ip, C. \& Patel, J. (1980) J. Nat. Cancer Inst. 65, 529-534.

8. Silver, H. K. B., Karum, K. A. Archibald, E. L. \& Salinas, F. A. (1979) Cancer Res. 39, 5036-5042.

9. Horgan, I. E. (1982) Clin. Chim. Acta 1/8, 327-331.

10. Dnistrian, A. M. \& Schwartz, M. K. (1981) Clin. Chem. 27, 1737-1739.

11. Katopodis, N., Hirshalut, Y., Geller, N. L. \& Stock, C. C. (1982) Cancer Res. 42, 5270-5275.

12. Werner, 1. \& Odin, L. (1952) Acta Soc. Med. Upsaliensis 57, 230-241.

13. Brozmanova, E. \& Skrovina, B. (1972) Neoplasma 19, 115123.

14. Warren, L. (1959) J. Biol. Chem. 234, 1971-1975.

15. Hirshaut, Y., Katopodis, N. \& Stock, C. C. (1981) Proc. Am. Assoc. Cancer Res. 22, 739.
$(20,22)$, and recurrence of disease $(20)$. The rapid postoperative decrease of sialic acid (fig. 2 ) is in contrast to two other studies $(23,24)$. Differences in sialic acid determination or types of cancer patients studied may be responsible for these contrasting studies.

Unlike tumor antigens, which are associated with a limited spectrum of tumors, increased sialic acid levels due to sialyltransferase activity and associated sialylglycoprotein production appear to be a common phenomenon of a variety of neoplastic cells. As a result, relatively nonspecific markers such as sialic acid and sialyltransferase or lipid-soluble sialic acid may have useful clinical applications as a cancer screen. The diagnostic effectiveness of sialic acid is better than that of CEA, one of the leading cancer screening tests. However, because of the technical problems involved in measuring sialic acid, sialyltransferase or lipid-soluble sialic acid, these assays have not been used widely. This simplified assay should enhance acceptance of the test. Even though there are false positives with arthritics and in patients with other inflammatory diseases, measurement of sialic acid is, however, dramatically easier than measurement of other cancer markers. In addition, $5-10 \%$ of false positives of normal patients also occur with CEA $(21,25)$. Other types of tests could be done in conjunction with an elevated sialic acid level to help with its diagnostic effectiveness.

16. Hogan-Ryan, A., Fennelly, J. J., Jones, M., Cantwell, B. \& Duffy, M. J. (1980) Brit. J. Cancer 4l, 587-592.

17. Mrochek, J. E., Dinsmore, S. R., Tormey, D. C. \& Waalkes, T. P. (1976) Clin. Chem. 22, 1516-1521.

18. MacBeth, R. A. L. \& Bekasi, J. G. (1962) Cancer Res. 22, $1170-1176$.

19. Moss, A. J., Bissada, N. K., Boyd, C. M. \& Hunter, W. C. (1979) Urology 13, 182-184.

20. Kiricuta, O., Bojan, O., Comes, R. \& Cristian, R. (1979) Arch. Geschwulstforsch. 49, 106-112.

21. Silver, H. K. B., Rangel, D. M. \& Morton, D. L. (1978) Cancer 41, 1497-1499.

22. Lipton, A., Harvey, H. A., Delong, S., Allegra, J., White, D.. Allegra, M. \& Davidson, E. A. (1979) Cancer 43, 17661771.

23. Hermann, W. P. \& Gielen, W. (1979) Arch. Dermatol. Res. 265, 321-329.

24. Dunzendorfer, U., Katopudis, N., Dnistrian, A. M., Stock, C. C., Schwartz, M. K. \& Whitmore, W. F. (1981) Invest. Urol. 19, 194-196.

25. Hansen, H. J., Snyder, J. J., Miller, E., Vandevoorde, J. P., Miller, O. N., Hines, L. R. \& Burns, J. J. (1974) Hum. Pathol. $5,139-147$.

Raymond J. Shamberger, Ph. D. Section Head of Enzymology Department of Biochemistry The Cleveland Clinic Foundation 9500 Euclid Avenue Cleveland, Ohio 44106 . USA 
